\title{
ANALYSIS OF ASSUMPTIONS OF THE ENVIRONMENT MANAGEMENT SYSTEM IMPLEMENTATION FOR THE SELECTED UNDERTAKING IN WASTE MANAGEMENT
}

\author{
Grzegorz Przydatek ${ }^{*}$, Rafał Krok \\ Technical Institute, State Vocational School in Nowy Sącz \\ *Corresponding author: e-mail: g.przydatek@gmail.com
}

\begin{tabular}{l}
\hline ARTICLE INFO \\
\hline Article history: \\
Received: September 2015 \\
Received in the revised form: \\
March 2016 \\
Accepted: April 2016 \\
\hline Key words: \\
transport of waste, \\
environmental management system, \\
ISO 14001 standard \\
\end{tabular}

ABSTRACT
The article presents the concept of the environmental management
system. Moreover, organization frames of the undertaking related to
eco-transport of waste were determined. Elements of the environmen-
tal management were characterized including the environmental
aspect. They were subjected to interpretation in terms of reduction of
the impact on the environment. In the context of constant improve-
ment, the attention was paid to the influence of the analysed organiza-
tion of its environmental activity. The objective of the paper is the
analysis of assumptions which follow from the ISO 14001 standard
including arrangement of the eco-transport of waste.

\section{Introduction}

According to Ogrodnik (2011) the environmental management system is a part of the organization management system used for development and implementation of its environmental policy and management of its environmental aspects. Solving the environmental problems is one of the most important challenges of modern world which decide on the further development of humanity in the world (Poskrobko, 1998). In relation to the growing pressure on the environment in the global dimension, the environmental management starts to be perceived as an effective solution which serves for improvement of the condition of the environment. The feature of the environmental management is its integration with the general system of management of an entity (Łaguna and Witkowska-Dąbrowska, 2010).

The application of the environmental management system in waste management should have a positive impact on the organization process including elements of environmental protection - oriented operations. On this basis the progressing trend in waste management requires optimization of steps on each stage starting from waste collection to their neutralization in order to increase its effectiveness.

The resolution of the Minister of Environment as of 11th January 2013 on detailed requirements concerning municipal waste collection from property owners constitute a considerable support for execution of technical and technological as well as sanitary requirements in the context of environmental management in waste logistics (Journal of Laws of 2013 item 122). The issues related to the environmental management gains more signifi- 
cance thus steps taken within this area have a direct or indirect impact not only on the environment but also on living conditions.

The objective of the paper is the analysis of assumptions which follow from the ISO 14001 standard including organization of the eco-transport of waste.

\section{Environmental policy}

The following parts of the article will analyse and describe particular stages of implementation of the environmental management including planning, checking and corrective actions as well as management review. The paper also includes references to organization of waste eco-transport.

According to Nierzwicki (2006) the environmental policy includes all plans and orientation of an organization concerning effects of environmental activity, formally expressed by the senior management. Besides, the environmental policy is considered to be the highest rank in the management system and includes an obligation to:

- constant improvement and counteracting pollution,

- meeting suitable requirements resulting from legislation and legal provisions referring to the environment and other requirements which concern environmental aspects of an organization.

Properties, with which environmental policy should be endowed, are as follows:

- it should suit the nature, scale and impact of its operation, products and services on the environment,

- it must constitute the frames of determination and review of objectives and environmental tasks,

- it must be documented, implemented, maintained and communicated to all employed persons who work on behalf of the entity,

- it must be available for public.

ISO 14001 standard shows clearly that the entity is to prevent pollution even when the waste management is carried out according to the applicable provisions of law. On the other hand, obligation to meet the requirements of law does not mean $100 \%$ of the guarantee that it will be always met (Nierzwicki, 2006).

\section{Planning}

Analysis of environmental aspects is the next stage of implementation of environmental management. The environmental aspect is an element of operation of an organization, its products and services, which may mutually interact with the environment (Nierzwicki, 2006). A disposal fleet is a source of the environmental aspect for an organization which deals with waste transport. In this case, fuel combustion will be an aspect and dust and gas emission to atmosphere will be an impact.

The other elements of planning, pursuant to ISO 14001 standard include legal requirements, objectives and tasks and environmental programs. Identified legal requirements are taken into account at setting up and implementation of the environmental management system. A special meaning is ascribed to regulations related to the environmental protection and obligations which thus arise. The last ones may result from possible emission of pollu- 
Analysis of assumptions...

tions to atmosphere as a result of fuel combustion processes in vehicles used for waste collection.

The objectives and tasks themselves should result from environmental reviews which were carried out. Each objective should be ascribed to a specific environmental task, which corresponds to detailed requirements concerning the environmental activity results (Bral, 2008). Reduction of fuel consumption by the disposal fleets is an exemplary objective while the task is fleet replacement to a new one with better performance and at the same time with lower impact on the environment. However, environmental programs constitute determined methods of achieving objectives and tasks including a specific time perspective and costs to be incurred.

\section{Implementation and functioning of the environmental management system}

After the planning stage the environmental management system is implemented. Organizations which deal with waste transport often adjust its activity to the requirements of environmental protection through implementation of ISO 14001 standard. These actions are carried out through (Nierzwicki, 2006):

- treating the environmental management as one of the priorities of the company's activity,

- making and maintaining the permanent contact with representatives of the parties interested in protection and improvement of the condition of the environment,

- determination of requirements and legal regulations concerning environmental aspects of the enterprise activity,

- developing the employees' interest in the environmental protection problems through a clear division of duties and the scope of responsibility, trainings, self-education, etc.,

- environmental planning including the entire cycle of the product life,

- ensuring necessary means for organization, education and investment purposes,

- developing a procedure of aiming to indicated levels of action,

- evaluating actions concerning the environment protection.

Implementation of the environmental management system is very favourable for the entity; it may, inter alia, strengthen its position on the market and increase demand on its services particularly among consumers with a higher level of ecological awareness (NyczWróbel, 2012). Waste transport organization according to the idea of sustainable development obliges carriers to have own vehicles which meet the requirements of Euro 6 standard. This standard, pursuant to the resolution (EC) No 715/2007 of the European Parliament and the Council of 20th June 2007 on the certification of approval of motor vehicles referred to emission of pollution from light passenger and utility cars (Euro 5 and Euro 6) and on the access to information concerning repair and maintenance of cars (Official Journal of the European Union of 2007, L 171/1) indicates, inter alia, the use of technical and technological solutions in vehicles which limit unfavourable impact of the fuel combustion process on the environment. In this context organizations which have implemented the environmental management system usually spent more money on environmental protection, including air protection, which was proved by Potoski and Prakash (2013). 
Capability of entities to carry out receipt and transport of waste with varied amount and quality requires having vehicles with a greater loading capacity for providing services to densely populated areas which distinguish with waste collection in replaceable and nonreplaceable containers (Korzeń, 2001). Also vehicles with a lower capacity with a 4-wheel drive for providing services to the areas which are difficult for access are utilised. It is particularly related to the mountainous areas in the winter time where precipitation is generally collected separately in non-replaceable containers. Additional support for realization of the environmental management during the waste disposal may consist in equipping the fleet in GPS and sensors which record data on waste unloading places (www. serwisy.gazetaprawna.pl).

Activity with regard to municipal waste collection from property owners is regulated, thus pursuant to the act of 13th September 1996 on maintaining cleanness and order in municipalities (JoL of 2013 item 1399 as amended) carriers are obliged to obtain the entrance to the registry in a municipality on the area of which they are going to collect municipal waste. Other organization requirement for waste disposal pursuant to the resolution of the Minister of Environment of 11th January 2013 on detailed requirements concerning collection of municipal waste from property owners (JoL of 2013, item 122), is having a warehouse and transport base in the location which has no impact on deterioration of the condition of the environment.

Pursuant to 14001 standard, the organizational structure of the entity should reflect employees' responsibility for entrusted tasks. The amount of waste and properties of waste location on a given area, the accepted standard of environment protection service, communication routes and local loading of environmental elements are indicators of tasks in waste logistics (Korzeń, 2001). The mentioned indicators influence shaping of business entities activity in the context of impact on the environment.

Efficiency of environmental management within the scope of objectives and tasks which are carried out, particularly requires determination and information on the role of responsibilities and rights (Ejdys et al., 2012). Except for encouraging employees to take part in the organization development, the key to the market success is clear formulation of employees' rights. In case of the disposal fleet, the responsibility as well as rights concerning the entrusted obligations should be treated as equal. It is also important to appoint in the organizational structure a representative authorized by the management to bear responsibility for implementation and supervision of the environmental protection system execution.

Trainings on the environmental management aim at raising ecological awareness in the context of constant improvement. The standard also includes the aspect of internal and external communication. The internal communication system in the organization which deals with waste transport is usually related to the exchange of information between the persons employed at waste collection and administrative employees. Internal communication includes transfer of information on changes related to the objectives, tasks, programs, which particularly impact the environmental aspects and on events which negatively influence the condition of the environment. It may be related to the increased consumption of fuel by a disposal fleet which results in the increase of the environmental fee. On the other hand, external communication provides for publishing to the interested parties environmental reports, which include information on objectives, aspects and environmental effects of an organization. 
Analysis of assumptions...

14001 standard allows great elasticity concerning preparing documentation. Documentation consists of documents concerning in particular elasticity, environmental objectives, tasks and description of the scope of the environmental management system. In the traditional system, there are three levels of documentation: strategic, tactical and operational. Additionally, the documentation includes the division into external and internal one including one formed by an organization (Nierzwicki, 2006). Documentation may concern the register of the amount of purchased fuel and environmental fees. Documents and records included therein determined by an organization are indispensable for planning and supervision of the processes related to considerable aspects of organization.

Operation control is a particularly significant element because it determines operations and actions, which correspond to the considerable environmental aspects (Ejdys et al., 2012). When providing a disposal fleet with diesel oil, verification of not only its use but also quality may be an element of the operational control related to the control of the organization impact on the environment. Worse quality of oil may result in a negative impact of the combustion process on the environment.

Moreover, in the environmental management, the organization should also introduce and maintain solutions concerning prevention, readiness and reaction to work accidents and serious faults. Their efficiency depends on the constant improvement which acc. to Deming's cycle should be considered as applicable (Lisowska-Mieszkowska, 2007). These solutions should include identification of all possible accidents and faults and preventive measures to such situations, namely measures which reduce the professional risk (Nierzwicki, 2006; Matuszak-Flejszman, 2009). The reasons for such industrial fault in transport may be self-ignition of waste collected in the vehicle. The efficiency of reduction of unfavourable effects for the environment is in this case related to suitable equipment with fire extinguishers and a correct reaction of the employees in order to minimize the threat.

\section{Verification and corrective measures}

As a part of verification, the organization should determine the principles for taking measurements, control and evaluation of effects of its environmental activity and to define the principles of proceeding during identification, assessment and further proceedings with discrepancies.

Monitoring, contrary to the measurement is a constant process consisting in the control of the monitored value (for example the amount of waste collected selectively) carried out according to strictly specified method in specific time. Monitoring of environmental parameters may be carried out through direct measurement, quality analysis or in an indirect manner through making specific calculations (Ejdys et al., 2012). On this basis knowing the amount of collected waste which are subject to a selective collection, it will be possible to determine an expected level of their recovery and recycling for advantageous reduction of the amount of disposed waste (Przydatek, 2012). 
Grzegorz Przydatek, Rafał Krok

According to ISO 14001 standard it is required to implement procedural activities which oblige an organization to carry out a periodical assessment of compliance with the applicable legal provisions and other, mainly concerning environmental protection. On this basis the act of 27th April 2001 Environmental protection law (Journal of Laws 1232 as amended) is a significant legal regulation on account of superior perspective of environmental protection and conditions of use of its resources including requirements of sustainable development. As a result of monitoring processes, the organization should undertake corrective and preventive actions. Undertaking corrective or preventive measures is related often to the investment inputs of the enterprise (Ejdys et al., 2012).

As a part of verification the recommended internal audit constitutes a comparison of the environmental management system with provisions of ISO 14001 standard and with documentation which describes this system. Nierzwicki (2006) except for the internal audit details the external audit. He included the internal audit to the first party audit which may be carried out by the organization itself. For example, within the area of this audit documented parameters of the purchased and consumed fuels may be verified. Another audit considered as the second party's audit is carried out by auditors of independent clients of the interested party for verification of justification for further cooperation. In case of operation of the waste disposal fleet the quality of the provided services by a particular entity will be a subject of such recognition. The external audit may be also considered as the third party's audit if it is carried out in compliance of the environmental management system with the requirements of the standard by independent auditors. On this basis the certifying unit makes a decision on granting a certificate. Obtaining this certificate confirms achieving a proper degree of compliance of the environmental management system of a given organization with the requirements of ISO 14001 standard (Christini et al., 2004; Ejdys et al., 2012; Živković et al., 2013).

\section{Review of management}

Pursuant to ISO 14001 standard, the management review is not required but recommended. However, it is a significant element on account of meeting the main requirements of the standard namely the process of constant improvement in order to ensure a correct functioning of the environmental management system. The above would not have been possible to be achieved without a current assessment of the environmental activity of the organization. As a result the review should lead to a decision and actions in case of evident changes concerning the guidelines of the environmental management system. In this context a difference between the arrangements of the internal audit and the result of the review will be noticeable (Nierzwicki, 2006).

The assumptions of the environmental management system lead to constant improvement of results of actions aiming at environmental protection (fig. 1). The most important from the point of view of the environmental standard of ISO 14001 series is that it must be integrated with the mechanism of strategic decisions related to the future of the enterprise and not only everyday management (Ejdys et al., 2012). 
Analysis of assumptions...

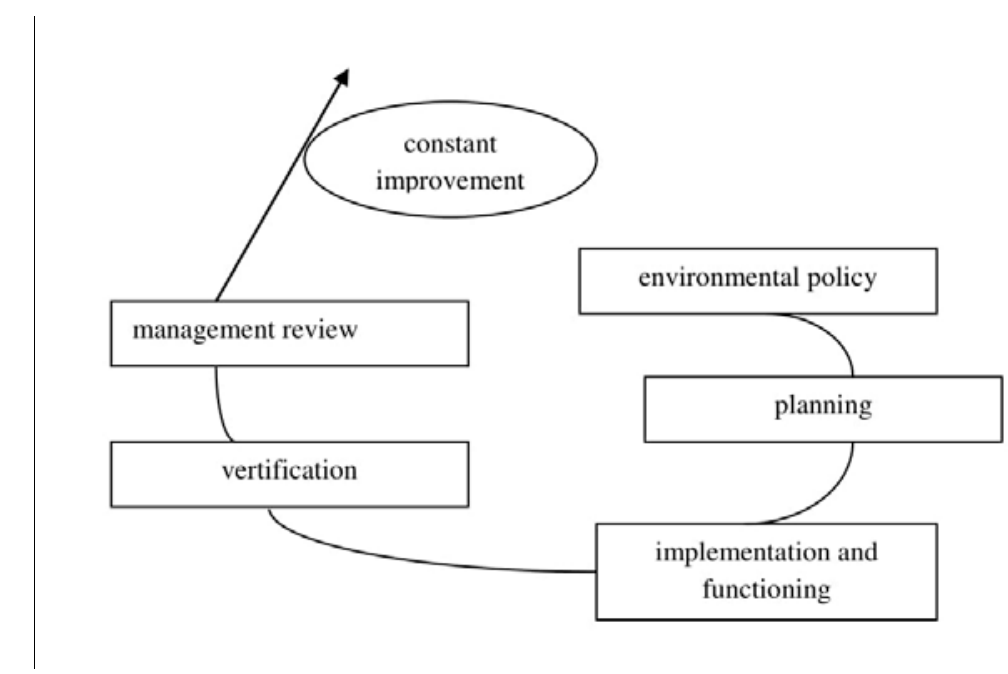

Figure 1. Process of implementation of environmental management system in the organization (Ejdys et al., 2012)

\section{Conclusion}

Based on the analysis of assumptions of the environmental management system implementation in the eco-logistics of waste the following conclusions should be made:

- implementation of the environmental management system by waste carriers should be related to minimization of the impact of their activity on the environment,

- obligation to reduce the fuel consumption or elimination of pollutants emission to atmosphere is a considerable environmental objective and the task consists in the replacement of a fleet to a new one with better performance and at the same time with a lower impact on the environment,

- communication, especially an internal one decides on the increase of awareness of the disposal fleet staff in the context of unfavourable environmental and economic effects which result from excessive fuel consumption,

- constant improvement should favour correctness and efficiency of operations for reduction of unfavourable effects for the environment in case of accidents and faults during the waste transport.

\section{References}

Bral, W. (2008). Obieg i ochrona dokumentów w zarzązaniu jakościa, środowiskiem i bezpieczeństwem informacj. Difin, Warszawa. ISBN 9788372518644.

Christini, G., Fetsko, M., Hendrickson, C. (2004). Environmental Management Systems and ISO 14001 Certification for Construction Firms. Journal of Construction Engineering \& Management. Vol. 130 Issue 3, 330-336. 
Ejdys, J., Kobylińska, U., Lulewicz-Sas, A. (2012). Zintegrowane systemy zarzadzania jakościa, środowiskiem $i$ bezpieczeństwem pracy. Wyd. Politechniki Białostockiej, Białystok. ISBN 9788362582211.

Korzeń, Z. (2001). Ekologistyka. Instytut Logistyki i Magazynowania. Poznań. ISBN 8387344702

Lisowska-Mieszkowska, E. (2007). Systemy Zarządzania Środowiskowego - Rozwój i Funkcjonowanie w Polsce. Ochrona Środowiska i Zasobów Naturalnych Nr 30, Warszawa, 5-24.

Łaguna, T.M., Witkowska-Dąbrowska, M. (2010). Zarządzanie zasobami środowiska. Wyd. Ekonomia i Środowisko. Olsztyn. ISBN 9788361643845.

Matuszak-Flejszman, A. (2009). Benefits of Environmental Management System in Polish Companies Compliant with ISO 14001. Polish Journal of Environmental Studies. Vol. 18, No. 3, 411-419.

Nierzwicki, W. (2006). Zarządzanie środowiskowe. Polskie Wydawnictwo Ekonomiczne ISBN 83- 208-1605-X. Warszawa.

Nycz-Wróbel, J. (2012). Świadomość ekologiczna społeczeństwa i wynikające z niej zagrożenia środowiska naturalnego (na przykładzie opinii mieszkańców województwa podkarpackiego). Zeszyty Naukowe Politechniki Rzeszowskiej, Nr 286, 63-76.

Ogrodnik, R. (2011). Identyfikacja aspektów środowiskowych jako podstawa opracowania systemu zarządzania środowiskowego w przedsiębiorstwie górniczym. Polskie Towarzystwo Zarządzania Produkcją, Opole.

PN-EN ISO 14001:2005 Systemy zarzadzania środowiskowego. Wymagania i wytyczne stosowania.

Poskrobko, B. (1998). Zarzadzanie środowiskiem. Polskie Wydawnictwo Ekonomiczne, Warszawa,

Potoski, M., Prakash, A. (2013). Do Voluntary Programs Reduce Pollution? Examining ISO 14001's Effectiveness across Countries. Policy Studies Journal, Vol. 41, Issue 2, 273-294.

Przydatek, G. (2012). Ocena wielkości selektywnej zbiórki odpadów na przykładzie wybranej gminy. Infrastruktura i Ekologia Terenów Wiejskich, 3, 209-218.

Rozporządzenie (WE) NR 715/2007 Parlamentu Europejskiego I Rady z dnia 20 czerwca 2007 r. w sprawie homologacji typu pojazdów silnikowych w odniesieniu do emisji zanieczyszczeń pochodzących z lekkich pojazdów pasażerskich i użytkowych (Euro 5 i Euro 6) oraz w sprawie dostępu do informacji dotyczących naprawy i utrzymania pojazdów (Dziennik Urzędowy Unii Europejskiej z 2007, L 171/1)

Rozporządzenie Ministra Środowiska z dnia 11 stycznia 2013 r. w sprawie szczegółowych wymagań w zakresie odbierania odpadów komunalnych od właścicieli nieruchomości (Dz.U. z 2013 r. poz. 122)

Ustawa z dnia 27 kwietnia 2001 r. Prawo ochrony środowiska (Dz. U. z 2013 r. poz. 1232 z późn. zm.)

Ustawa z dnia 13 września 1996 r. o utrzymaniu czystości i porządku w gminach (Dz. U. z 2013 r. poz. 1399 z późn. zm.)

Živković, S., Takić, L., Živković, N. (2013). The improvement of environmental performances by applying ISO 14001 standard - a case study. Chemical Industry \& Chemical Engineering Quarterly. Vol. 19 Issue 4, 541-552.

GPS w śmieciarkach. (on-line). Obtained from: http://serwisy.gazetaprawna.pl/samorzad/ artykuly/683627,gps_w_smieciarkach_od_lipca_to_bedzie_obowiazek.html. 


\section{ANALIZA ZALOŻEŃ WDROŻENIA SYSTEMU ZARZĄDZANIA ŚRODOWISKOWEGO DLA WYBRANEGO PRZEDSIĘWZIĘCIA W GOSPODARCE ODPADAMI}

Streszczenie. W artykule zdefiniowano pojęcie systemu zarządzania środowiskowego, określono ramy organizacyjne przedsięwzięcia związanego z ekotransportem odpadów. Scharakteryzowano składowe zarządzania środowiskowego, w tym zidentyfikowano aspekt środowiskowy. Poddano je interpretacji $\mathrm{w}$ aspekcie zmniejszenia presji na środowisko. W kontekście idei ciągłego doskonalenia, zwrócono uwagę na wpływ analizowanej organizacji na efektywność jej działalności środowiskowej. Celem pracy jest analiza założeń wynikających z zapisów normy ISO 14001 przy uwzględnieniu organizacji ekotransportu odpadów.

Słowa kluczowe: transport odpadów, system zarządzania środowiskowego, norma ISO 14001 